\title{
IdeAs
}

Idées d'Amériques

$11 \mid 2018$

Modernités dans les Amériques : des avant-gardes à aujourd'hui

\section{Reassessing Modernisms in Light of Jerome Rothenberg's Work}

Repenser les modernismes à la lueur de l'œuvre de Jerome Rothenberg

Repensar el modernismo bajo la lupa de Jerome Rothenberg

\section{François Hugonnier}

\section{OpenEdition}

\section{Journals}

Electronic version

URL: https://journals.openedition.org/ideas/2750

DOI: 10.4000/ideas. 2750

ISSN: 1950-5701

\section{Publisher}

Institut des Amériques

\section{Electronic reference}

François Hugonnier, "Reassessing Modernisms in Light of Jerome Rothenberg's Work", IdeAs [Online] 11 | 2018, Online since 19 June 2018, connection on 20 October 2022. URL: http:// journals.openedition.org/ideas/2750 ; DOI: https://doi.org/10.4000/ideas.2750

This text was automatically generated on 20 October 2022

\section{(i)

Creative Commons - Attribution-NonCommercial-NoDerivatives 4.0 International - CC BY-NC-ND 4.0 https://creativecommons.org/licenses/by-nc-nd/4.0/ 


\title{
Reassessing Modernisms in Light of Jerome Rothenberg's Work
}

\author{
Repenser les modernismes à la lueur de l'œuvre de Jerome Rothenberg \\ Repensar el modernismo bajo la lupa de Jerome Rothenberg
}

François Hugonnier

Nothing changes from generation to generation except the thing seen and that makes a composition.

- G. STEIN ${ }^{1}$

1 Throughout his career as a poet and anthologist, Jerome Rothenberg has dug out the ancestors of early $20^{\text {th }}$-century modernisms in order to highlight groundbreaking pieces, regardless of their modes of telling or spatio-temporal coordinates. As modernist poetry is now canonized by university presses and makes up a literary heritage, Jerome Rothenberg's work leads one to wonder whether the powerful modernist rupture can be found again. Was it unprecedented? Was is really a break? Was it unique, done and over with? Rothenberg's work maps out a plurality of "modernisms", as Peter Nicholls calls them, by revisiting and redefining them. He even tends to move away from the words "modernism" (artistically) and "modernity" (historically) by speaking rather of "avant-garde" poetry in the 1914-1945 period. As Nicholls underlines in Modernisms: A Literary Guide, this plurality of modernisms is to be traced outside of the North-American context of the early $20^{\text {th }}$ century, for instance when, he notes, Stéphane Mallarmé and Arthur Rimbaud both prefigured "modernist innovation" and were "pledged to an art radically at odds with accepted norms and limits" (Nicholls, P., 1995: 34). Jerome Rothenberg's anthologies confirm Nicholls's definition of modernism's "largely indeterminate" beginning and ending, "a matter of traces rather than of clearly defined historical moments", the first traces, according to Nicholls still, being found in a "certain complexity of tone", rather than a "new urban" content (1). Jerome Rothenberg has contributed to the tracing of international and transmedia modernisms mostly by exploring avant-garde poetry and its paradoxical yet complementary occurrences in remoter, uncharted territories, the upshot of which 
is a more fundamental questioning on the nature of the poetic act itself. His explorations reveal a similar radicalism in the Futurists' poems and manifestos (a radicalism to be understood in terms of form and concept rather than content, as Nicholls claims [85]) and in tribal poetics seemingly at odds with this modernist movement's aesthetic interest in technology and progress. Rothenberg's work calls into question the use of the words "modern" ("designed and made using the most recent ideas and methods", or "of the present or recent times, especially the period of history since around 1500") and "modernist" ("relating to or a member of the modern art movement" ${ }^{3}$, that is to say, to rephrase the debatable notions of "member[ship]" and "movement", a body of works, or artists and writers, showing a common innovative drive after the Industrial Revolution, in the late $19^{\text {th }}$ and early $20^{\text {th }}$ century).

2 In his 1968 anthology Technicians of the Sacred, Jerome Rothenberg had boldly asserted that "Primitive means complex" (Rothenberg, J., 1968: xxv), a statement which helped rethink linguistic and socio-political precepts. As a self-proclaimed heir to significant modernist poets (among them Stein, Pound and Williams), Rothenberg "took Charles Olson's interests in ancient cultures in a new direction" (Yépez, H., 2013), and has demonstrated poetry's relevance in a post-war context in the Americas and worldwide.

3 Yet, neither the adjectives "modernist" nor "post-modernist" fit the scope of Rothenberg's work. Chronologically, Rothenberg's work comes after the successive international waves of modernism, in poetry and visual arts, spanning mainly the $1910 \mathrm{~s}$ to 1950 s, and retains their epistemological methods and radical impulses ${ }^{4}$. Despite its historical coincidence with postmodernism (prompted first in architecture and then by the French post-structuralists), with which it shares a playful indulgence in constant intertextuality, irony and self-reference, Rothenberg's poetry does not show much interest in the materiality of the words on the page or in the artificiality of writing (as the $\mathrm{L}=\mathrm{A}=\mathrm{N}=\mathrm{G}=\mathrm{U}=\mathrm{A}=\mathrm{G}=\mathrm{E}$ poets, including Rothenberg's close friend Charles Bernstein would). If both the adjectives "modernist" and "post-modernist" might partly contribute to a definition of Rothenberg's poetry, we should conversely observe how his theoretical work allows to redefine them.

4 By using Rothenberg's poems, translations and anthologies as a point of departure for a wider reassessment of modernisms, this paper aims at revisiting not only 1914-1945 avant-garde American poetry, but also earlier and later international outputs (including performance, magic, ritual, oral, and outsider poetry). Embracing folklore and turning away from epic poetry, Rothenberg "make[s] it new" (Pound E., 1956: 263) by disclosing some of the predecessors and successors of modernism, as well as the lesser known acts of its canonized yet wobbly time frame. We will wonder whether Rothenberg's poems, and most of all his anthologies, merely repeat the Poundian gesture or go past its achieved, canonized heritage.

5 First, we will explore some of the sources that preceded the poetic avant-garde's surfacing at the beginning of the $20^{\text {th }}$ century. Then, the issue of poetry and sociopolitical engagement will be addressed. Finally, we will show how Rothenberg's anthologies, in line with Robert Duncan's “symposium of the whole” (Duncan R., 2011: 153), map out the Pan-American and global inscriptions of modernity on a wider historical and geographical scope. 


\section{Early Sources}

6 Even though Rothenberg's activities as a performance poet and anthologist span the second half of the $20^{\text {th }}$ and the early $21^{\text {st }}$ centuries, we might arguably refer to his approach as both modern and post-modern. Pre- or proto-modern might even be more accurate to define his appropriation of the various waves and shades of modernism. Rothenberg selects works from the canonized American modernist poets (Pound, Williams) as well as similar sources originating from different times and spaces. According to him, the acts of putting together an anthology, or generating variations on the poems of others (The Lorca Variations, 1993) or else writing poems of his own are part of "the same project" (Rothenberg, J., 2010). The notions of owning and authorship are to be rethought, as highlighted by Yves di Manno, who uses the French word “"propre"” (“'own"'), in inverted commas, to refer to Rothenberg's poems (Di Manno Y., 2007, 665). Be it in his collections of poems or anthologies, Rothenberg freely picks poems, lines, words, associative techniques (Gematria, 1994) or marginal practices (tribal and oral poetry) that he revisits in his own work, most of which draws from ancient sources to shed light on a universal poetic impulse that can hardly be spotted on a restrictive time line.

7 Rothenberg probes international sources, publishes or republishes them alongside his own voice as a poet, in his poems and/or comments (hence his systematic "Commentar[ies]", "Pre-faces" and "Post-faces"). The multiple comments and crossreferences (for instance when poems are derived from the numerical value of other poets' names in Gematria, or else with the use of dedication and marginal notes in $A$ Book of Witness, 2002) transform the poetic I into an anthological appropriation of voices, both personal and plural. Consequently, Rothenberg's reconfiguration of, and move away from modernism should be sought in his essays, anthologies and poems, all of which participate in the elaboration of a paradoxically specific radical stance. During interviews, he recurrently refers to Donald Allen's authoritative anthology The New American Poetry 1945-1960, which canonized the transition from the so-called last generation, or second wave of modernism, to post-modernism. John Ashbery, Paul Blackburn, Robert Creeley, Robert Duncan, Allen Ginsberg, Jacques Kerouac, Denise Levertov, Michael McClure, David Meltzer and Charles Olson were featured, to name but the most famous. If Rothenberg's early writings coincide with that moment in history, his own poetic investigations echo the radicalism of early $20^{\text {th }}$-century modernist poets.

While Rothenberg shares common ground with the Objectivists, retaining some of their views, he pursues his own experimentations in world perception and poetic practice. Similarly, the aforementioned Blackburn, Creeley, Duncan, Ginsberg, McClure, Meltzer and Olson are, to some extent, influential fellow poets, but Gertrude Stein, whose work paradoxically feels contemporary today, is quoted or alluded to in most of his books, including his introduction to Revolution of the Word: A New Gathering of American AvantGarde Poetry 1914-1945, which reevaluates the most innovative modernist works (here simply referred to as "avant-garde") from a global perspective ${ }^{5}$. If this anthology zooms in specifically on the usually acknowledged peak-moment of modernist poetry, interestingly enough, it features the best-known poets of the time (Marcel Duchamp, Ezra Pound, e.e. cummings, H.D., T. S. Eliot, Wallace Stevens, Charles Olson, George Oppen, Louis Zukofsky, Mina Loy, Marianne Moore, etc.) alongside with significant 
works from lesser known poets like Elsa von Freytag-Loringhoven, Abraham Lincoln Gillespie or Walter Conrad Arensberg, an art collector close to Duchamp whose poem "Ing" opens the collection':

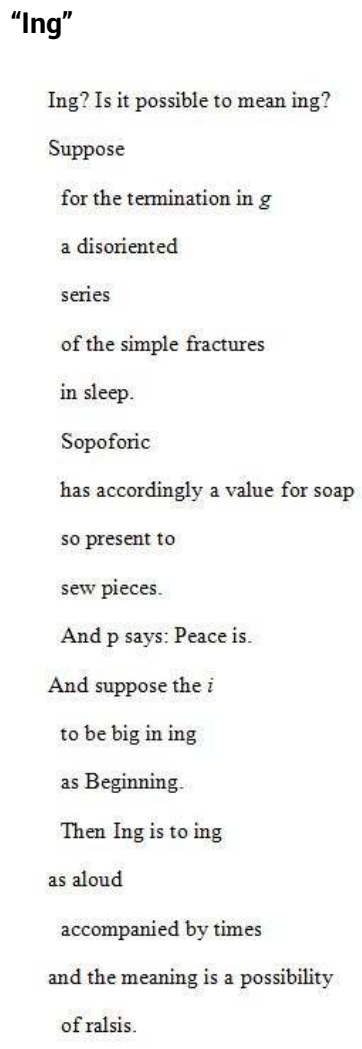

9 Arensberg's puns, repetitions and rearranged letters ("mean ing" is fragmented, "Peace is" is in pieces, etc.) are reminiscent of ee cummings' riddles. This poem also recalls Stein's deconstruction of language and particularly her own use of the -ing form. It is no accident if Jerome Rothenberg chose her words to be quoted first in this anthology. In the final analysis, Stein, the avant-garde poet and art collector (whom he discovered as a teenager, along with Rimbaud and Lorca ${ }^{7}$ ) stands as one of the seminal poets in Rothenberg's work. A bit like the Objectivists whose work only came to the fore decades after they ignited change, Stein retrospectively stands out as a particularly radical, underrated and often misunderstood modernist poet and theorist that Rothenberg invites to consider in depth so as to redefine, first of all, the poetic act. As Gertrude Stein explains in "Poetry and Grammar", originally published in her 1935 collection of essays Lectures in America, the poetic act consists in naming:

Nouns are the name of anything. Think of all that early poetry, think of Homer, think of Chaucer, think of the Bible and you will see what I mean you will really realize that they were drunk with nouns, to name to know how to name earth sea and sky and all that was in them was enough to make them live and love in names, and that is what poetry is it is a state of knowing and feeling a name. (quoted in Rothenberg J. and Quasha G., 1973: 82; also quoted in Rothenberg J. and Joris P., 1995: 105)

These words by Gertrude Stein, which articulate poetic theory and practice, testify to the poet's search for linguistic appropriateness. Stein channels her senses and gets to the crux of things by simplifying the syntax and the punctuation, by using repetition, 
variation and internal rhymes. What is striking in this excerpt is the way she precisely plays with grammatical conventions, the way she tests and tastes the words to define her vision, setting aside pre-established linguistic restrictions. Stein is lifting the veil of unnecessary linguistic ornament or constraint, all of which suggests that poetry should not be limited by any rules. Yet in order for it to be poetry, the poets needs to use words, however revised, repeated or reshaped. Stein disregards the rules of metric along with the deeper grammatical preconstructions of language, while paradoxically remaining true to poetic expression. Indeed, if the poet is the namer, the one who sees and seizes things, names should connect within or without grammatical boundaries. In Rothenberg's reading and appropriation of Stein's propositions, the poet would then be a namer, and, I should add, a translator through whom changes might occur. Stein's crucial words are further discussed by Jerome Rothenberg and George Quasha in the anthology America A Prophecy. In their own words, they explain the aim of their chapter entitled "A Book of Rites and Namings":

In its primary processes-naming and defining-language is itself a poetic act, which becomes remarkable when it revives its latent power to bring about change.

A Book of Rites \& Namings attempts to reveal the variety of poetic uses in the bare operation of language-its vocabulary and grammar-as well as the deliberate extension of those uses in the work of individual poets. (Rothenberg J. and Quasha G., 1973: 79)

11 While, according to Stein, the act of naming is itself a poetic act, whose goal is defining, according to Rothenberg, the poet is both a definer and a re-definer. The "bare operation of language" is found in the works of such "individual [American] poets" as George Oppen or Charles Reznikoff. The will to name things with an unburdened clarity of perception, and the intended quality of the poem as object, hark back to ancient questions on the nature of language. Against all odds, the premises of Stein's radical use of repetition, variation and word cutting in the process of defining are found, by Rothenberg, not so much in the works of her canonized American contemporaries but in primitive sources worldwide.

In the magazine Alcheringa (1970-1980) and several of his anthologies, Jerome Rothenberg has probed the roots of poetry in ancient languages, symbols, images, signs and emblems. In "Origins \& Namings", the first chapter of Technicians of the Sacred: A Range of Poetries from Africa, America, Asia, Europe \& Oceania, Rothenberg retraces the history of the first poetic inscriptions on the globe. "Genesis" is related in several parts thanks to narratives originating from varied places. The selection called "The Pictures" (Rothenberg, J., 1968: 26-31) is a series of images whose layout relates the birth of language. Starting from bare drawings, these pictures gradually turn into narrative sequences. Going past the Western biases of reading and writing by following vertical, horizontal, circular and spiraling patterns, they question the nature of language and the modes of representation available to the poet. Ezra Pound's use of Chinese ideograms paved the way for Jerome Rothenberg's later primitive discoveries. Conversely, his collage "The Pictures" comprises poetic works that prefigure the manifold media modernist poets would experiment with centuries later. Rothenberg's poetic explorations have unearthed ancient practices by wandering through the past, raising such issues as the viability of investigating the past while verging on plunder. Indulging in translation, appropriation and re-production, these explorations have paradoxically underlined the shortcomings of occidental resources and reached out to the socio-political sphere. 


\section{The Art of the Manifesto} rid of limitative dogmas on a socio-political level. Rothenberg's efforts at including and translating world poetry resisting grammatical and canonic Western frames might pave the way towards wider changes within the social groups. In his ideal view of poetry, cognitive and linguistic frames would be revised and broadened through the reevaluation of the poet's performance, set at the heart of the social group in tribal contexts. Ultimately, this broadening of poetic practice would trigger linguistic, social and political progress. As far as Rothenberg's anthology Technicians of the Sacred is concerned, its publication date, 1968, coincides with international revolt. This decisive anthology, which was derived from Claude Lévi-Strauss and Mircea Eliade's anthropological methods ${ }^{8}$, underlined an urge to recover primitive forms of poetic expression. Looking back on the 1960s in various interviews (Action Poétique, 2009), Rothenberg claims that poetry used to have a significant social role in the United States. As Allen Ginsberg's well-known friendship with Bob Dylan or the Beatles illustrates at mainstream level, the belief that song- or poetry-writing could change the world was stronger and more popular than ever before, or ever since. Whether prompted by chance or design, the chronological coincidence of Technicians of the Sacred's publication and the laudatory way in which Rothenberg and some of his contemporaries look back on the late 1960s reveal an idealized view of poetry's sociopolitical interplay. that the publication of Technicians of the Sacred was the most important poetic event of 1968, a decisive year for American poetry, in light of other crucial works by Oppen, Blackburn, Ginsberg, Mac Low and Pound. In retrospect, Weinberger defines that time as a moment when the world of poetry and the world at large were one, when poetry was closely linked to political change. As it typifies the 1968 poets' will to gather voices and democratize poetry (as in Oppen's of Being Numerous), Weinberger sees Technicians of the Sacred as one of the leading attempts at generating an enlargement of the poetic act. Moreover, he underlines an interesting parallel between the increasing recognition, both generic and geographical, of the primitive poetic act and the rise of concomitant social changes.

Although Rothenberg's anthology is representative of the American poetic practices of the time, he should not be considered, in Donald Allen's own terms, a poet "in the American grain" (the young Rothenberg had not been included in either sections of Allen's The New American Poetry 1945-1960). On the contrary, according to Allen still, Rothenberg belongs to the new "international school" of poets (Action Poétique, 29, original emphasis). Rothenberg's investigations enable us to get a broader view of worldwide poetics when it comes to naming, to finding the word and changing the world, from a historical, geographical and theoretical standpoint. In addition, his reassessment of international poetry in various anthologies balances the representation of world cultures. By discovering local outputs, the reader may notice that one-line Eskimo poems have the same spare power as haikus, or say, Dada puns:

(1) An Eskimo Poem for the Sun

The sun up there, up there 
(2) A Bushman Poem for the Blue Crane

A splinter of stone which is white ${ }^{9}$ apart (by name or by description); given its own tune, too, to make it special; fixed, held fast in all this vanishing experience. It is this double sense of sighted/sited that represents the basic poetic function" (Rothenberg, J., 1985: 147). Going back to barebone poetic babble involves seizing the moment and the vision by getting rid of inherited linguistic inadequacy and unnecessary phraseology. Therefore, Rothenberg's work implies that the poetic act, that is, the act of naming and defining, would be no less than a struggle against normative precepts in the humanities, which includes circumventing the limitations of institutionalized research nationally and opening to foreign manifestations of ground-breaking poetry. To put it simply, Rothenberg's aim is to find back the original poetic impulse by overcoming the temptation of ethnocentered Western poetry, while his method is inherited from the radical modernists' art of manifesto.

During interviews and speeches, Rothenberg often quotes William Carlos Williams's piece of advice, delivered to him at the City College of New York in the 1950s: "Seize the language! Smash it to hell! You have a right to it!" ${ }^{10}$ The words of the great modernist poet are themselves a variation on Eugene Jolas's 1929 "Revolution of the Word": "The literary creator has the right to disintegrate the primal matter of words. [...] He has the right to use words of his own fashioning and to disregard existing grammatical and syntactical laws" (quoted in Rothenberg, J., 1974: 148-153). As Marjorie Perloff explains in her 2004 essay on Eugene Jolas, by contributing to this linguistic revolution, the poets who signed the "Revolution of the Word" manifesto, including Hart Crane and Harry Crosby, were already campaigning for "racial and ethnic equality" (Perloff, M., 2004: 85). The acknowledgment of oppressed peoples and cultures required decades of interdisciplinary labor that Rothenberg undertook, in his turn, as one of its spokesmen starting from the early 1960s. With help from Diane Rothenberg, he actually invented a hybrid form of poetry and a whole new field of research, ethnopoetics. Rothenberg is part of a generation of poet-scholars who do not try to "[write] it new" as much as they search, appropriate, publish and share interdisciplinary propositions.

Should we then consider Rothenberg's poetics as part of the modernist tradition and legacy? Jerome Rothenberg has recycled modernism, used its tools and tried to go past its achievements. The prefix "post" in "post-modernism" indicates that modernism was not over with after World War II, and some of its workings existed before. Marc Amfreville, Antoine Cazé and Claire Fabre provide an interesting definition of modernism as far as its artistic spark is concerned: "a period of intense innovative creativity" and "questioning of values and artistic conventions" (Amfreville M., Cazé A. and Fabre C., 2010: 169, my translation). But such a radical approach to art and language springs from a universal drive, regardless of space and time. As all artistic forms repeatedly innovate, such a definition of modernism cannot suffice. Undoubtedly, the questioning of conventions surfaced sharply in modernist works at the beginning of the $20^{\text {th }}$ century and in the inter-war period. And then again, the word "modernism" itself bears witness to its paradoxical temporality, as the period's name and works are both informed by the past, present and future (as evidenced by Futurism). From our contemporary perspective, modernism paradoxically fits in 
literary history as both the continuity of Symbolism and Romanticism, and a phase in which the paradigm of a radical rupture was explored to the point of exhaustion ${ }^{11}$.

What is more, the paradox of modernism is not only temporal, it is generic as well. Some modernist poets did not fit in with the radical definition we have been attempting so far. For example, as it reverses the modernists' revolutionary approach to language, values and norms, T. S. Eliot's poetry is considered by Rothenberg, using yet another phrase of Williams's, as the "great disaster to our letters"12. According to them (and others, like Marjorie Perloff, one of the first scholars who questioned Eliot's modernist legacy), Eliot's influential The Waste Land slowed down the emerging vision of poetry as an unadorned orchestration of speech, by forcing so-called literary greatness back into the modernist landscape. Rothenberg's stance echoes Meschonnic's claim that modernity is not a movement (contrary to Pound's modern Imagism or Rothenberg's post-modern Deep Image movement), and that any attempt at defining modernism and modernity as a whole is fragmentary and limitative (Meschonnic, H., 1988: 26). Rothenberg's anthology sections and selections rethink these literary categorizations by envisioning the poets canonized in the main waves of modernism and post-modernism in the larger timeframes and aftermaths of the two World Wars ${ }^{13}$. Such landmarks are unambiguous as far as their chronology is concerned. Furthermore, as a leading, yet marginal anthologist, Rothenberg does not use the words "modernist" and "postmodernist" often, and connects poetic impulses from very different spatio-temporal sources, which tends to weaken these adjectives and turn them into loose labels.

As far as his own poetic debut is concerned, Jerome Rothenberg explained in 2010 that he initially turned to poetry as "the vehicle for the transformation of language and thought" in the post-World War II context (Rothenberg, J., 2010). The wars chronologically began and ended what he considers the high point of poetic avantgardism (ie modernism, 1914-1945). Both wars stand out as key landmarks in his anthologies and poems: like most Beat poets, Rothenberg used poetry as an instrument for change after Auschwitz and Hiroshima, which happened when he was a young teenager. This has been a life-long process, epitomized by the unspoken trauma in Poland/1931 (1974), a book of poetry veiled by fantasy and linguistic experiments when trying to recover his lost origins, which was eventually rendered into direct poetic speech fifteen years later in Khurbn (the Yiddish word for "disaster"). Jerome Rothenberg's trip to Poland in the 1980s triggered his turn towards a new form of investigative poetry:

IN THE DARK WORD, KHURBN

all their lights went out

their words were silences,

memories

drifting along the horse roads

onto malkiner street

a disaster in the mother's tongue

her words emptied

by speaking

returning to a single word

the child word

spoken, redeyed on

the frozen pond

was how they spoke it,

how I would take it from your voice 
\& cradle it

that ancient and dark word

those who spoke it in the old days

now held their tongues ${ }^{14}$

The transformation (of thought and speech, of the memories, testimonies and imagination of both the poet and his ancestors) starts in the "word", whose "emptiness" (156), "dark[ness]" (155) and "silences" (155) are paradoxically voiced through the poem. The poet is both a son inheriting from a "mother tongue", and a father giving birth to a new "ancient and dark word" he intends to utter, "cradle" and raise throughout the collection. The wording of the disaster thrives in contradiction and resists translation, as evidenced by the ancestors who "held their tongues" (155), or else by the title itself, "Khurbn", which epitomizes the need to revert to another language, the language of lost origins, when facing the unspeakable. Thus, the "ancient, dark word" soon starts resisting the repeated "empt[ying]" $(155,156)$ that Rothenberg witnessed in Poland. With its paradoxical, iterated presence, it articulates the humming silence of a new beginning. Moreover, in the same way as he mixes English and Yiddish words to come up with a poetic answer, Rothenberg weaves actual testimonies into the fabric of his voice and the voices of others still, the victims of the Holocaust who perished and could not speak. This polyphonic composition is orchestrated by the reading of actual fragments of testimony found in buried scrolls, by the poet's physical investigation on the site of the disaster and the use of his poetic voice and imagination. Rothenberg's initiative enables to resist aphasia by channeling fragmented testimony and memory into an oralized creative work.

Whether in dark or lighter pieces, the notion of actual poetic and socio-political change is openly embraced. It is often fantasized and parodied by Rothenberg, as evidenced by his collection A Paradise of Poets, in which the tongue-in-cheek line "I will create a fiction which shall express great things" fills page 72 . Rothenberg speaks consciously of the marginalization of poetry, yet poets from his generation, participating in readings and happenings in the 1960s, had high hopes for poetry's ability to modify speech processes (the Deep Image movement worked towards new ways of grasping visual and linguistic content). If these speech processes were put to the fore, they could gradually open the grammatical, syntactical and, outside of pragmatic poetics, institutional and political boundaries of their time. If he admittedly looks back on his debut as coinciding with a climax of this shared hope for a recognition of poetry's social power, Jerome Rothenberg still links poetic and political aims in his marginal and innovative approach to poetry, especially as far as the publishing process is concerned.

In fact, in the $21^{\text {st }}$ century, Jerome Rothenberg keeps promoting the art of the manifesto, developed by Pound or Marinetti as early as the 1900-1930s. It was taken up by Rothenberg and others in the 1960s and 1970s in poetry journals and magazines, and it has most lately emerged in digital form on the internet, with such participating websites as Jacket2, featuring as one of its websites-within-the-website, Rothenberg's Poems and Poetics, whose introductory lines read:

In this age of internet and blog the possibility opens of a free circulation of works (poems and poetics in the present instance) outside of any commercial or academic nexus. I will therefore be posting work of my own, both new \& old, that may otherwise be difficult or impossible to access, and I will also, from time to time, post work by others who have been close to me, in the manner of a freewheeling on-line anthology or magazine. I take this to be in the tradition of autonomous publication 
by poets, going back to Blake and Whitman and Dickinson, among numerous others. links to other works provided by fellow poets. The publication of the poems and their related commentaries is done instantly. This revolutionary, "freewheeling" anthology accelerates the tedious process of publication and remains "outside" of any constraint or institution. Of course, one could be tempted to argue that it does not have the same scientific value as a traditional peer-reviewed academic book. But on the contrary, peers can intervene and exchange their views, which provides a new kind of expertise and broadening of Rothenberg's overall perspective. If this foreword is reminiscent of the modernist manifestos, it is also, as Rothenberg enthusiastically puts it, inscribed in the older "tradition" of self-publication. Interestingly enough, this practice of poetry enables both a thorough freedom of expression of the individual author (Rothenberg as a critic and poet) and the audience (viewers sharing the poems and comments). Rothenberg's blog illustrates how published poetry can return to a more direct participative exchange, not unlike the tribal poetry he had been witnessing and promoting in the 1960s and 1970s.

Be it in the 1910s, 1960s, 1970s or 2010s, the aim of radical poets has remained the same: articulating poetic practice and social transformation. Whether in his poems and anthologies, in his live performances or on his blog, Rothenberg epitomizes the current revival of interest, by scholar-poets, in the modernist art of manifesto. Like Charles Bernstein for instance, Rothenberg writes pre- and post-faces to his own works and to the works of others, prose pieces providing contextual and theoretical elements that are inseparable from the poems. In turn, the poems are themselves inseparable from the translations and selections in his anthologies, whose ground-breaking angles always make them large-sized manifestos as well. Through the publication of poems attached to commentaries and meta-commentaries, Rothenberg unearths forgotten practices from the Kabbalistic (numerical value of words), Native American (oral poetry) and worldwide tribal traditions, undertaking a global gathering of poetry that amounts to an interdisciplinary struggle against linguistic entrapment and ethnocentrism. His daily use of the internet, where he is notably completing an ongoing anthology of outsider poetry ${ }^{16}$, confirms his position as a visionary, global poet, a position inherited from the most radical trends of modernism as well as earlier poets like William Blake.

\section{Towards Pan-American and Global Inscriptions}

Jerome Rothenberg has kept the radical engagement of his modernist predecessors to ignite change in his own time. He has not only looked into the past to make new poetry, he has also looked closer, especially in the margins, at many misrepresented radical poetic practices worldwide. This search for old and new poetic sparks echo the early $20^{\text {th }}$-century European and North-American modernisms in different spatio-temporal frames. As one of the leading Jewish-American poets, Rothenberg willingly questions his own outsider position when he playfully defines himself as a "secular-secular poet", rather than a "secular Jewish poet" (Rothenberg, J., 2010). In other words, his work and identity should not be reduced to ethnic or national epithets, whether "Jewish" or "American". Jewish cultures have been a research topic, just as South-American and 
Amerindian cultures have provided new materials and new directions. Hence his view of the Diaspora and, more importantly here, of artistic radicalism, is to be understood globally. Marina Tsvetayeva's phrase "all poets are Jews" (Tsvetayeva, M., "Poem of the End", 1971: 87) is often reemployed by Rothenberg (after Paul Celan) to highlight the fact that radical poets are outsiders. This sense of exclusion, repeatedly expressed by Jewish poets, is quoted and rephrased by Rothenberg who claimed that "conversely-all Jews are not poets":

It was in the sense of such an outsiderness-and placing it clearly in "this most Christian of worlds" that Marina Tsvetayeva spoke of all poets as Jews-much like Norman Mailer's "White Negro" of the1950s. That was in her poem "Poem of the End," later quoted by Paul Celan in the Cyrillic epigraph to his own poem "Und mit dem Bluch aus Tarussa" and by me in A Big Jewish Book, where it became a central proposition of the stand I was then taking. [Right here, in an aside, I pointed out: "Of course-conversely-all Jews aren't poets."] My argument here wasn't for some kind of Jewish exclusiveness but for a recognition that such resistances existed both there and elsewhere and that my address, in Tsvetayeva's sense, was to "all poets" or to all poets who share the outrider stance or to all, poets and others, who resist the rule of totalizing states and constrictive religions. I was myself-then as nownot writing in a specifically Jewish context for a Jewish audience, as such, but opening the Jewish mysteries to all who wanted them. (Rothenberg, J., 2008: 55)

The "outsider"/"outrider" position of Rothenberg as a radical poet is to be understood as aiming at the recognition of all kinds of radical poetic expressions on the globe. This is how Rothenberg's ethnopoetic explorations, both inside and outside a so-called "Jewish context", unveiled ritual or tribal poetries emerging within various ethnic groups, none of which were deemed relevant by literary standards. These practices had remained mostly unknown due to a language barrier as much as a mutual ignorance from primitive groups and literary circles.

One of the first steps was to open up the canon to under-represented poetic forms in the Americas. It involved a rethinking of ethno-centered and logo-centered perceptions of literary creation by including oral poetry and magic. The following poem ${ }^{17}$ is the translation of an oral poetry performance: 
(1)

$\mathrm{T}$

h

e

The animals are coming

n

i

$\mathrm{m}$

a

1

S
$\mathrm{HEH} \mathrm{EH} \mathrm{H} \mathrm{E} \mathrm{H}$

H E H E H H E H

H E H U H H E H

H E H E H H E H

H E H E H H E H oral poetry performance he attended during one of his stays at the Seneca reservation in New York State. This is an example of what he calls "total translation"18. As many sounds and chants are being translated, the poem is not complete or effective until it is performed. This translation is reminiscent of a score, it is the written trace of an oral content based on repetition, intonation and rich musical variations that make the performance highly hypnotic, as suggested here by the arrangement of capital letters ("HE", "UH"). In the original Seneca context, the sacred animals are the guardians of the ceremony, which means that the song has an incantatory quality. As Rothenberg explained during the conference on "Total Translation" in Le Mans (2009), on the occasion of which he performed several Native-American poems, these "songs without words" are both minimalist and sophisticated. He explained that they were representative of "the mystic society of shamans", underlining the key role of the orator within the social group.

Likewise, the influential tribal improvisations and translations by the South-American medicine woman María Sabina, whose poems were selected and edited by Jerome Rothenberg ${ }^{19}$, can be considered a key sample of outsider poetry. During her lifetime, Sabina invited some of the most famous North-American artists to experiment drugrelated hallucinatory speeches whose goal was the broadening of consciousness, and whose outcome was the enhancement of creativity and linguistic practice. These visions are part of what Jerome Rothenberg calls "dreamworld" (Rothenberg, J., 2010), and more precisely of a marginal and magical "transform[ation]" of "language and thought" by a shaman whose performances were recorded. In Sabina's words, quoted by Rothenberg as an epigraph to the first section of his poetry collection A Book of Witness (Rothenberg, J., 2002): "Language belongs to the saint children. They speak and I have 
the power to translate" (the "saint children" are in fact magic mushrooms). Sabina's chants are assimilated to a form of outsider oral poetry that recalls the liberating qualities of the formal experimentations undertaken by modernist poets. Translating visions, sounds and languages participates in Sabina's and Rothenberg's collective widening of poetry. In the same way as the modernists would disregard grammatical rules and try picture-poems or ideograms, Sabina and other marginal poets for instance Native American ones engage in oral poetry.

In light of oral poetry in the Americas, Jerome Rothenberg's global anthologies have provided surprising inter-cultural parallels and analogies. The true poets, the namers who position themselves on the margins of language, are misrepresented because they belong to the small nucleus of the primitive social group. The avant-gardist happenings and poetry readings of the early $20^{\text {th }}$ century, which surfaced again in the 1950s and 1960s in the United States, have predecessors and followers worldwide in tribal contexts. Moreover, if we were to follow Rothenberg's all-encompassing poetics of outsiderness, it might be argued that the radical refashioning of language generated by modernist poets is taken up today by female, LGBT or disabled writers (in the 1950s, the counter-culture writers of the Beat Generation were similarly fascinated by the "marginalized cultures which were never represented in public", namely AfricanAmerican and gay cultures, as Ginsberg put $\left.\mathrm{it}^{20}\right)$. The common radicalism and marginal position of these groups throughout the generations and the socio-political contexts is striking. Indeed, Rothenberg has greatly contributed to what Robert Duncan had called a "symposium of the whole" (153). If Whitman's mid-19 $9^{\text {th }}$ century democratization of poetry, arising between Blake and Rimbaud's visionary poetics in Europe, enabled to open the poetic I to the masses, other American poets in the $20^{\text {th }}$ century, including Ginsberg, Duncan and Rothenberg, had to take up this broadening by opening poetry to all forms of beings, to all cultures and languages. Rothenberg's poetics is thus visionary and plural in mode, as well as democratizing and totalizing in scope. Here is an extract from his ethnopoetics anthology named symposium of the Whole after Duncan's phrase:

What we're involved with here is a complex redefinition of cultural and intellectual values: a new reading of the poetic past and present that Robert Duncan speaks of as "a symposium of the whole." In such a new "totality," he writes, "all the old excluded orders must be included. The female, the proletariat, the foreign; the animal and vegetative; the unconscious and the unknown; the criminal and failure -all that has been outcast and vagabond must return to be admitted in the creation of what we consider we are." (Rothenberg J. and D., 1983: xii-xiii).

These words call for an intense democratization of the poetic voice. The desire for total representation has been deeply grounded in American poetry since the $19^{\text {th }}$ century, but had remained partial and unfulfilled until the contribution of modernist and postmodernist poets, especially in the 1920s, 1950s and 1960s. As Rothenberg keeps implying in forewords and intertextual references, Walt Whitman is the first poet whose "I" effectively started speaking for the "multitudes": "Do I contradict myself? Very well then, I contradict myself. (I am large, I contain multitudes)" ${ }^{21}$. By using the words of another in a later context, Jerome Rothenberg encourages diachronism and dialogue, as well as the expression of paradox and contradiction. After Ginsberg's Howl (1956) and Duncan's "symposium of the whole", he welcomes resistance and cultural difference, using poetry collections and worldwide anthologies to articulate a plural I/ eye. These voluminous international anthologies, which can be thought of as the continuation of the modernists' undertakings with the Long Poem, as suggested by 
Xavier Kalck and Clément Oudart (2016: 6), also create a totalizing experience of poetry, be it mainstream or marginal. Technicians of the Sacred, published in August 2017. In the new millennium, whatever the dominating literary currents, Jerome Rothenberg remains attached to a singular practice of poetry which has stood the test of time, as he keeps mapping out worldwide past and present outsider poetry, and reasserts the need to rethink restrictive categorization and fight against ethnocentrism. One may also consider that he keeps appropriating the works and methods of others. While the early modernists looked for ancient Greek, Chinese and Japanese alternatives to the corseted Victorian verse, Rothenberg has led Kabbalistic and tribal investigations on the very act of naming after colonization and the unspeakable events of World War II, which had a tremendous impact on his formative years (Rothenberg, J., 2010). As an heir to the "Revolution of the Word" and a pre-modern post-Beat-and-what-not definer, he still believes in poetry's revolutionary power. As a poet and anthologist, he militates for a dialogic representation of the multiple identities that the radical poets-witnesses, namers and tricksters-embody in their a-temporal struggle against univocity and cultural hegemony. grounded in specific historical upheavals, as illustrated by such collections of his own poems as Poland/1931 (1974) or Khurbn (1989), which retrace the author's personal and communal Polish origins through historical testimony and the imagination in a reversed journey from West to East, from the present to the past, from the unspoken to the spoken. Therefore, poetry could be thought of as a "vehicle for the transformation of language and thought" (Rothenberg, J., 2010) repeatedly springing within a unique context. While the universal impulse does not change, individual poets respond to historical specificities. The "thing seen" (Stein, qtd. in Rothenberg, J., 1974: xi) differs and generates new works through the "Eye of Witness", as Rothenberg put it, looking back on his lifelong poetic achievements ${ }^{22}$.

Thanks to Rothenberg's advances, the term "modernist", which carries a strong temporal, not to mention epochal promise, is recast, while new considerations on contextual-geographic and historical-poetic responses emerge. As it turns out, one of the most represented modernist artists in Rothenberg's work is Kurt Schwitters. If we now try to trace some of their common grounds through specific samples of their works, after World War I and World War II, Kurt Schwitters's Revolving (1919) ${ }^{23}$ and Jerome Rothenberg's Khurbn (1989) reflect new modes of representing and telling. Both of them are investigative compositions made out of fragments, venturing beyond the limitations of their respective media (art and poetry). While Revolving is a collage of broken objects evoking the war's impact on our ability to represent, as well as the urgent need to rise again, rebuild and "make it new", Khurbn is a poetic tour de force following Rothenberg's visit of World War II's concentrations camps in which he let the voices of the unheard victims soar through a polyphonic poetic voice, both testimonial and incantatory. The specificities of Revolving and Khurbn remind us that radicalisms are to be understood dialogically and diachronically. In the aftermath of the two World Wars, these works recycle and revolutionize the raw materials of representation in order to formulate a necessary response to the call of History. 


\section{BIBLIOGRAPHY}

Action Poétique, Special issue: Techniciens du sacré (Jerome Rothenberg, Isabelle Garron, Auxeméry, Yves di Manno, Eliot Weinberger), nº 195, March 2009.

Allen, Donald, The New American Poetry 1945-1960, New York, N.Y., Grove Press, 1960.

Amfreville, Marc, Antoine Cazé et Claire Fabre, "Le modernisme (1900-1930)", Histoire de la littérature américaine, Paris, Presses Universitaires de France, 2010.

Besnault-Levita, Anne and Anne-Florence Gillard Estrada, eds., Beyond the Victorian/ Modernist Divide: Remapping the Turn-of-the-Century Break in Literature, Culture and the Visual Arts. New York, N.Y., Routledge, 2018.

Cambridge Dictionary. Available on line: https://dictionary.cambridge.org. Accessed May 15, 2018.

Di Manno, Yves, « Entrée des chamans », Postface, Les Techniciens du sacré, Paris, José Corti, coll. «Merveilleux », n 35, 2007.

Duncan, Robert, "Rites of Participation”, The H.D. Book (collected essays 1959-1964) I.6, Berkeley, CA, University of California Press, 2011, p. 153-199.

Eliade, Mircea, Shamanism. Archaic Techniques of Ecstasy (Le chamanisme et les techniques archaïques de l'extase, Paris, Payot, 1951, 1968), trans. Willard R. Trask, Princeton, N.J., Princeton University Press, 1964, 1972.

Eliot, T.S. The Waste Land (1922), Collected Poems 1909-1962, London, Faber \& Faber, 1963.

Kalck, Xavier and Clément Oudart, "Introduction. Critical Dimensions: Sizing the American Long Poem. Dimensions critiques: mesures du poème long américain", Revue française d'études américaines, $\mathrm{n}^{\circ} 147,2016 / 2$.

Ginsberg, Allen, Howl, Kaddish and Other Poems (1956, 1961), New York, N.Y., Penguin Classics, 2009.

Meschonnic, Henri, Modernité modernité, Paris, Gallimard/Verdier, 1988.

Nicholls, Peter, Modernism: A Literary Guide, Berkeley, CA, University of California Press, 1995.

Oppen, George, Of Being Numerous (1968), New Collected Poems, edited with an introduction and notes by Michael Davidson, preface by Eliot Weinberger, New York, N.Y., New Directions, 2002, p. 161-208.

Perloff, Marjorie, “'Logocinéma of the Frontiersman': Eugène Jolas's Multilingual Poetics and Its Legacies", Differentials: Poetry, Poetics, Pedagogy (chapter 5), Tuscaloosa, Al.: The University of Alabama Press, 2004.

Pound, Ezra, The Cantos (1956), New York, N.Y., New Directions, 1993.

Rothenberg, Jerome, A Book of Witness: Spells \& Gris-Gris, New York, N.Y., New Directions, 2002.

----. Alcheringa (1970-1980), Jerome Rothenberg and Denis Tedlock eds. Full Archive. Available on line: http://jacket2.org/reissues/alcheringa-archive-journal-ethnopoetics-1970-1980. Accessed May 15, 2018.

----. Gematria, Los Angeles, CA, Sun \& Moon Press, 1994.

----. "Interview with Jerome Rothenberg", conducted by François Hugonnier, University of Le Mans, October 14, 2010. 
----. Khurbn \& Other Poems, New York, N.Y., New Directions, 1989.

----. The Lorca Variations, New York, N.Y., New Directions, 1993.

----. María Sabina: Selections. Poets for the Millennium, edited with a preface (and commentaries) by Jerome Rothenberg (including essays by Alvaro Estrada, R. Gordon Wasson and Henry Munn), Berkeley, CA, University of California Press, 2003.

----. New Young German Poets, San Francisco, CA, City Lights, 1959.

“Outsider Poems, a Mini-Anthology in Progress", Poems and Poetics. Available on line: http:// poemsandpoetics.blogspot.com/. Accessed May 15, 2018.

----. Poems and Poetics. Available on line: http://poemsandpoetics.blogspot.com/ (Accessed May 15, 2018); https://jacket2.org/commentary/jerome-rothenberg (Accessed May 15, 2018).

----. Poetics \& Polemics 1980-2005, Selected and edited by Jerome Rothenberg and Steven Clay, Introduction by Hank Lazer, Tuscaloosa, Al., The University of Alabama Press, 2008.

----. Poland/1931, New York, N.Y., New Directions, 1974.

----. Revolution of the Word: A New Gathering of American Avant-Garde Poetry 1914-1945, Boston, Mass., Exact Change, 1974.

----. Shaking the Pumpkin: Traditional Poetry of the Indian North Americas, (New York, DoubledayAnchor Press, 1972), Revised Edition, Albuquerque, N.M., University of New Mexico Press, 1991.

----. Songs for the Society of the Mystic Animals (Seneca, with typographical realizations by Ian Tyson), London, Tetrad Press, 1980.

----. Technicians of the Sacred: A Range of Poetries from Africa, America, Asia, Europe \& Oceania (1968), Second Edition, Revised and Expanded, Berkeley, CA, University of California Press, 1985.

----. Technicians of the Sacred: A Range of Poetries from Africa, America, Asia, Europe \& Oceania (1968, 1985), Revised and Expanded, 50th Anniversary, Berkeley, CA, University of California Press, 2017.

----. Les Techniciens du sacré, version française établie par Yves di Manno, Paris, José Corti, coll. « Merveilleux », $\mathrm{n}^{\circ}$ 35, 2007.

----. "Total Translation" (conference, translation workshop and performance by Jerome Rothenberg), organized by Hélène Aji, University of Le Mans, November 20, 2009.

----. Triptych (Poland/1931, Khurbn, The Burning Babe), New York, N.Y., New Directions, 2007.

----. White Sun Black Sun, New York, N.Y., Hawk's Well Press, 1960.

Rothenberg, Jerome and Pierre Joris, Poems for the Millennium: From Fin-de-Siècle to Negritude (vol. 1), Berkeley, CA, University of California Press, 1995.

----. Poems for the Millennium: From Postwar to Millennium (vol. 2), Berkeley, CA, University of California Press, 1998.

Rothenberg, Jerome and Diane, "Pre-Face", Symposium of the Whole: A Range of Discourse toward an Ethnopoetics, Berkeley, CA, University of California Press, 1983, p. xii-xiii.

Rothenberg, Jerome and George Quasha, America A Prophecy: A New Reading of American Poetry from Pre-Columbian Times to the Present, New York, N.Y., Random House, 1973.

Rothenberg, Jerome and Jeffrey C. Robinson, Poems for the Millennium. The University of California Book of Romantic and Postromantic Poetry (vol. 3), Berkeley, CA, University of California Press, 2009. 
Rothenberg, Jerome and Herinerto Yépez, Eye of Witness: A Jerome Rothenberg Reader, Boston, Mass., Black Widow Press, 2013.

Schwitters, Kurt, Revolving, 1919, wood, metal, cord, cardboard, wool, wire, leather, and oil on canvas, New York, N.Y., MoMA. Available on line: https://www.moma.org/collection/works/ 79211. Accessed May 15, 2018.

Stein, Gertrude, Lectures in America, New York, N.Y., Random House, 1935.

Tsvetayeva, Marina, "Poem of the End", Selected Poems (1971), trans. Elaine Feinstein, New York, N.Y., Penguin Books, 1994.

Weinberger, Eliot, “New York / 1968”, Joy! Praise! Rothenberg at 60 (A festschrift for Jerome Rothenberg on the Occasion of his Sixtieth Birthday), Pierre Joris ed., Encinitas, CA, Ta'Wil Books and Documents, 1991.

Whitman, Walt, Leaves of Grass / Feuilles d'herbe, Édition bilingue, trans. Roger Asselineau, Paris: Aubier-Flammarion, 1972.

Workman, Chuck, The Source: The Story of the Beats and the Beat Generation, 1999. Film.

Yépez, Herinerto, "Introduction to Eye of Witness: A Jerome Rothenberg Reader" (August 28, 2013). Available on line: https://jacket2.org/commentary/heriberto-y\%C3\%A9pez-introduction-eyewitness-jerome-rothenberg-reader. Accessed May 15, 2018.

\section{NOTES}

1. Gertrude Stein, qtd. by Jerome Rothenberg in "Pre-face", Revolution of the Word: A New Gathering of American Avant-Garde Poetry 1914-1945 (Boston, Mass., Exact Change, 1974, xi).

2. "Modern", Cambridge Dictionary. Available on line: https://dictionary.cambridge.org (Accessed May 15, 2018).

3. "Modernist", Cambridge Dictionary, op. cit.

4. Jerome Rothenberg's first books were published in 1959 (translation) and 1960 (poetry). See Jerome Rothenberg, New Young German Poets, San Francisco, CA, City Lights, 1959. See also White Sun Black Sun, New York, N.Y., Hawk's Well Press, 1960.

5. "Nothing changes from generation to generation / except the thing seen / and that makes a composition." (Gertrude Stein, quoted in Jerome Rothenberg, "Pre-face", Revolution of the Word: A New Gathering of American Avant-Garde Poetry 1914-1945, Boston, Mass., Exact Change, 1974, xi).

6. Walter Conrad Arensberg, "Ing", in Jerome Rothenberg, Revolution of the Word: A New Gathering of American Avant-Garde Poetry 1914-1945, op. cit., 4-5.

7. "Interview with Jerome Rothenberg", conducted by François Hugonnier, University of Le Mans, October 14, 2010.

8. The title Technicians of the Sacred originates from Eliade's repeated reference to the shaman as a "technician of the sacred" (Eliade, M., 1964: 33).

9. Jerome Rothenberg, "Images", Technicians of the Sacred: A Range of Poetries from Africa, America, Asia, Europe \& Oceania (1968), Second Edition, Revised and Expanded, Berkeley, CA, University of California Press, 1985, 147.

10. William Carlos Williams, quoted by Jerome Rothenberg in Poetics \& Polemics 1980-2005 (Tuscaloosa, Al., The University of Alabama Press, 2008, 57).

11. See Anne Besnault-Levita and Anne-Florence Gillard Estrada, eds., Beyond the Victorian/ Modernist Divide: Remapping the Turn-of-the-Century Break in Literature, Culture and the Visual Arts. New York, N.Y., Routledge, 2018. 
12. William Carlos Williams, quoted by Jerome Rothenberg in Revolution of the Word: A New Gathering of American Avant-Garde Poetry 1914-1945 (Boston, Mass., Exact Change, 1974, xiii, xx).

13. See Jerome Rothenberg and Pierre Joris, Poems for the Millennium: From Postwar to Millennium, (vol. 2), Berkeley, CA, University of California Press, 1998. See also Rothenberg, Revolution of the Word: A New Gathering of American Avant-Garde Poetry 1914-1945, op. cit.

14. Jerome Rothenberg, Khurbn (New York, N.Y.: New Directions, 1989), later collected in Triptych (New York, N.Y.: New Directions, 2007), 155.

15. Jerome Rotenberg, Poems and Poetics. Available on line: http:// poemsandpoetics.blogspot.com/ (Accessed May 15, 2018); https://jacket2.org/commentary/ jerome-rothenberg (Accessed May 15, 2018).

16. "Outsider Poems, a Mini-Anthology in Progress". Poems and Poetics. Web. http:// poemsandpoetics.blogspot.com/ (24 October 2017).

17. Jerome Rothenberg, "12 Songs to Welcome the Society of the Mystic Animals", Shaking the Pumpkin: Traditional Poetry of the Indian North Americas, (New York, Doubleday-Anchor Press, 1972), Revised Edition, Albuquerque, University of New Mexico Press, 1991, 15. (See also Jerome Rothenberg, Songs for the Society of the Mystic Animals [Seneca, with typographical realizations by Ian Tyson, London], Tetrad Press, 1980).

18. "Total Translation" (conference, translation workshop and performance by Jerome Rothenberg), organized by Hélène Aji, University of Le Mans, November 20, 2009.

19. María Sabina: Selections. Poets for the Millennium, edited with a preface (and commentaries) by Jerome Rothenberg (including essays by Alvaro Estrada, R. Gordon Wasson and Henry Munn), Berkeley, CA, University of California Press, 2003.

20. Allen Ginsberg, in Chuck Workman, The Source, The Story of the Beats and the Beat Generation, 1999. Film.

21. Walt Whitman, "Song of Myself" ("51"), in Leaves of Grass / Feuilles d'herbe, édition bilingue, trans. Roger Asselineau, Paris: Aubier-Flammarion, 1972, 176. Quoted in Rothenberg J., 2002: 55.

22. Rothenberg, Jerome and Herinerto Yépez, Eye of Witness: A Jerome Rothenberg Reader, Boston, Mass., Black Widow Press, 2012.

23. Schwitters, Kurt, Revolving, 1919, wood, metal, cord, cardboard, wool, wire, leather, and oil on canvas, New York, N.Y., MoMA. Available on line: https://www.moma.org/collection/works/ 79211. Accessed May 15, 2018.

\section{ABSTRACTS}

More than moments in history, the complex terms "modernism" and "modernity" need reassessing. Therefore, by using Rothenberg's work as a point of departure for a wider reassessment of modernisms, this paper aims at revisiting not only 1914-1945 avant-garde American poetry, but also earlier and later international outputs (including performance, magic, ritual, oral, and outsider poetry). Embracing folklore and turning away from epic poetry, Rothenberg discloses some of the predecessors and successors of modernism, as well as the lesser-known acts of their canonized yet wobbly time frame. As a poet and anthologist, he militates for a dialogic representation of the multiple identities that the radical poets-witnesses, namers and tricksters-embody in their struggle against univocity and cultural hegemony. This paper first sets out to explore Rothenberg's handling of the sources preceding the poetic avant- 
garde's surfacing at the beginning of the $20^{\text {th }}$ century. Then it addresses the issue of poetry and socio-political engagement, spanning the 1910-1970 era. Finally, it illustrates how Rothenberg's anthologies map out the Pan-American and global inscriptions of modernisms on a wider historical and geographical scope. If Rothenberg's work highlights the universal impulse of the most radical trends of international modernisms, it also defines poetic resistance as a contradictory yet necessary contextual response to the call of History.

Plus que des moments historiques, les termes complexes «modernisme » et "modernité » méritent d'être réexaminés. Par conséquent, en prenant comme point de départ l'œuvre de Jerome Rothenberg pour repenser plus largement les modernismes, cet article envisage de revisiter non seulement la poésie américaine avant-gardiste des années 1914 à 1945, mais aussi des sources internationales antérieures et postérieures (qui incluent performance, magie, rituel, poésie orale et marginale). S'emparant du folklore et tournant le dos à la poésie épique, Rothenberg dévoile certains prédécesseurs et successeurs du modernisme, ainsi que des acteurs moins reconnus de cette période certes canonisée, mais instable. En tant que poète et anthologiste, il milite pour une représentation dialogique des identités multiples que les poètes ceux et celles qui nomment, témoignent et dupent - incarnent dans leur lutte contre l'univocité et l'hégémonie culturelle. Cet article propose d'abord d'explorer la manière dont Rothenberg explore les sources anticipant le surgissement de l'avant-garde au début du $20^{\text {ème }}$ siècle, puis d'analyser les rapports entre poésie et engagement socio-politique. Il s'agira enfin d'observer la manière dont les anthologies de Rothenberg œuvrent pour la cartographie des inscriptions panaméricaines et mondiales des modernismes sur une plus grande échelle historique et géographique. Si les travaux de Rothenberg mettent en lumière l'impulsion universelle des tendances les plus radicales des modernismes internationaux, ils définissent aussi la résistance poétique comme une réponse, contextuelle et nécessaire, à l'appel de l'Histoire.

Más que momentos históricos, los términos ambiguos de "modernismo" y "modernidad" se refieren a un acercamiento al arte y a la escritura que merece un nuevo examen. Por consiguiente, aplicando la metodología de Jerome Rothenberg, este artículo se propone revisitar no solo la poesía vanguardista estadounidense de los años 1914 a 1945, sino también fuentes internacionales anteriores y posteriores (que incluyen performance, magia, ritual, poesía oral y marginal). Al apropiarse del folklor y al dar la espalda a la poesía épica, Rothenberg desvela la identidad de algunos de los predecesores y sucesores del modernism, así como actores menos reconocidos de aquel período ya canonizado, es cierto, pero inestable. Como poeta y antólogo, milita para una representación dialógica de las identidades múltiples que los poetas -los y las que nombran, testimonian y embaucan- encarnan en su lucha contra la univocidad y la hegemonía cultural. Este artículo pretende, primero, explorar las fuentes que anticipan el surgimiento de la vanguardia al principio del siglo XX, y luego analizar las relaciones entre poesía y compromiso sociopolítico. Se tratará de observar cómo las antologías de Rothenberg contribuyen a cartografiar las inscripciones panamericanas y mundiales de la modernidad a una mayor escala histórica y geográfica. Si los trabajos de Rothenberg echan luz sobre el impulso universal de las tendencias más radicales del modernismo, también definen la resistencia poética como una respuesta, contextual y necesaria, al llamado de la Historia.

\section{INDEX}

Palabras claves: Jerome Rothenberg, modernismo estadounidense, antología, poesía, radical

Keywords: Rothenberg, modernism, anthology, poetry, radical

Mots-clés: Jerome Rothenberg, modernisme, anthologie, poésie, radical 


\section{AUTHOR}

\section{FRANÇOIS HUGONNIER}

François Hugonnier est maître de conférences en littérature américaine à l'université d'Angers.

Sa thèse de doctorat porte sur les interdits de la représentation dans les œuvres de Paul Auster et Jerome Rothenberg. Il est l'auteur de nombreux travaux sur la poésie américaine et la littérature post-11 septembre, dont une monographie sur Falling Man de Don DeLillo (Presses Universitaires de Paris Nanterre, 2016).

François Hugonnier is Associate Professor of American Literature at the University of Angers, France. His PhD dissertation deals with the restrictions of representation in Paul Auster and Jerome Rothenberg's works. He has published numerous essays on American poetry and post-9/11 literature, including a monography on Don DeLillo's Falling Man (Presses Universitaires de Paris Nanterre, 2016). 